\title{
Effects of Hetero Elements and Nanopores on Lithium Insertion/Extraction in Polyacrylonitrile-Based Carbons
}

\author{
Norio TAKAMI*, Asako SATOH and Takahisa OHSAKI
}

Received June 1, 1998 ; Accepted August 10, 1998

\begin{abstract}
Lithium insertion into polyacrylonitrile-based carbons heated from 800 to $1200{ }^{\circ} \mathrm{C}$ was studied to be used as high capacity anodes for lithium-ion batteries. The carbons heated from 1000 to $1200{ }^{\circ} \mathrm{C}$ showed a potential plateau near $0 \mathrm{~V}$ vs. $\mathrm{Li} / \mathrm{Li}^{+}$in the charge-discharge potential curves and reversible capacities of 407 to 517 $\mathrm{mAh} / \mathrm{g}$, higher than that of $\mathrm{LiC}_{6}(372 \mathrm{mAh} / \mathrm{g})$. The reversible capacity in the potential range for 0.5 to $2 \mathrm{~V}$ increased with the nitrogen/carbon and the hydrogen/carbon atomic ratio. Nanopores (voids) with a radius of around $2 \mathrm{~nm}$ were remarkably observed in the PAN-based carbons heated at $1200{ }^{\circ} \mathrm{C}$. Solid state ${ }^{7} \mathrm{Li}$ nuclear magnetic resonance observation and small angle X-ray scattering measurements suggested that lithium species inserted can be classified into ionic lithium in the layer structure and in the unorganized carbon containing hetero elements, and lithium clusters with metallic character in the nanopores.
\end{abstract}

\section{INTRODUCTION}

Lithium insertion in disordered carbons prepared with heat treatments from 550 to $1400{ }^{\circ} \mathrm{C}$ has been extensively studied to find promising anode materials for lithium-ion batteries. ${ }^{1-17)}$ The disordered carbons are characterized as two types; carbon materials heated from 550 to $1000{ }^{\circ} \mathrm{C}$, and hard carbons heated from 1000 to $1400{ }^{\circ} \mathrm{C}$. The former ones heated below $1000{ }^{\circ} \mathrm{C}$ have high reversible (extraction) capacities of 500 to 800 $\mathrm{mAh} / \mathrm{g}$ with large potential hysteresis. ${ }^{2,48-10,12,14-16)}$ The latter hard carbons heated from 1000 to 1200 ${ }^{\circ} \mathrm{C}$ have high reversible capacities of about 600 $\mathrm{mAh} / \mathrm{g}$ with little potential hysteresis near $0 \mathrm{~V}$ vs. $\left.\mathrm{Li} / \mathrm{Li}^{+} .1,6,7,13,17\right)$ These disordered carbons contain condensed aromatics or micropores, or both. Some hetero atoms (e.g., $\mathrm{H}, \mathrm{O}$, and $\mathrm{N}$ ) remain in the disordered carbon materials. Lithium insertion in the disordered carbons containing hydrogen or nitrogen has been studied. , $8,10,16,18-22)^{\text {It }}$ is known that the high capacity and the large hysteresis in charge-discharge curves are correlated to the hydrogen/carbon $(\mathrm{H} / \mathrm{C})$ atomic ratio of disordered carbons heated below $1000{ }^{\circ} \mathrm{C} .{ }^{4,816}$ ) The nitrogen content strongly affects the irreversible capacity as

Material and Devices Research Laboratories, Research and Development Center, Toshiba Corporation (72, Horikawa-cho, Saiwai-ku, Kawasaki, 210-8572, Japan)

Key Words: PAN-based Carbons, Lithium Insertion/Extraction, Hetero Elements, Nanopores reported in the case of carbons containing nitrogen $\left(\mathrm{N}_{\mathrm{z}} \mathrm{C}_{1 . \mathrm{z}}\right)$ prepared by chemical vapor deposition (CVD). ${ }^{18)}$

A number of mechanisms have been proposed to explain the lithium insertion in the disordered carbons with high capacities. ${ }^{4,5,712,14,16)}$ The effect of residual hetero atoms on lithium insertion in the hard carbons has not been well analyzed..$^{8,19,21)}$

In this paper, we selected polyacrylonitrile (PAN)-based carbons heated from 800 to $1200{ }^{\circ} \mathrm{C}$ as the hard carbons containing some hetero atoms in order to investigate the effects of residual hetero atoms and nanopores on lithium insertion by the charge-discharge test, elemental analysis, small angle X-ray scattering (SAXS) measurements, and solid state ${ }^{7} \mathrm{Li}$ nuclear magnetic resonance $\left({ }^{7} \mathrm{Li}\right.$ NMR) observation.

\section{EXPERIMENTAL}

PAN (Aldrich Chemical Co.) was heated at $210^{\circ} \mathrm{C}$ for $5 \mathrm{~h}$ in an air. After cooling, the meterial was heated between 800 and $1200{ }^{\circ} \mathrm{C}$ in an argon. The obtained PAN-based carbons were mixed with $3 \mathrm{wt} \%$ of poly-tetrafluoroethylene binder. The electrodes $(2 \times 2 \mathrm{~cm})$ were prepared by pressing the mixtures on a stainless steel mesh collector, followed by drying under vacuum at $200{ }^{\circ} \mathrm{C}$ for 12 $h$ before use. The charge (insertion)-discharge (extraction) cycle tests for the carbon electrodes were carried out using a three-electrode glass cell. 
The cell and electrode construction were the same as those described previously. ${ }^{11}$ The electrolytes were a $1 \mathrm{M}$ solution of $\mathrm{LiPF}_{6}$ in a mixture $1: 1$ by volume of ethylene carbonate and diethyl carbonate (Tomiyama Pure Chemical).

Charge-discharge tests were carried out by charging to a $0 \mathrm{~V}$ vs. $\mathrm{Li} / \mathrm{Li}^{+}$for $30 \mathrm{~h}$ with a current density limit of $0.25 \mathrm{~mA} / \mathrm{cm}^{2}$ and discharging to $2 \mathrm{~V}$ at $0.25 \mathrm{~mA} / \mathrm{cm}^{2}$.

Powder X-ray diffraction (XRD) measurements were made on a Rigaku diffractometer equipped with $\operatorname{CuK} \alpha$ a radiation. The average lattice constant $\boldsymbol{d}_{002}$ was obtained from the position of the Bragg peak using the Bragg equation. SAXS data were collected using Rigaku diffractometer (RU-200) with $\mathrm{CuK} \alpha$ radiation operating in transmission mode. The sample $(350 \mathrm{mg})$ was packed into a stainless steel holder $(4 \times 52 \times 2$ $\mathrm{mm}$ ). A radius of spherical voids (nanopores) was estimated from the radius distribution function calculated from the SAXS profiles with Fourier transformation.

The PAN-based carbons without binder were used for solid state ${ }^{7} \mathrm{Li}$ NMR measurements and prepared by drying a suspension of the sample in acetone on nickel foil under vacuum for $1 \mathrm{~h}$. ${ }^{7} \mathbf{L i}$ NMR spectra were measured using a solid state ${ }^{7} \mathbf{L i}$ NMR spectrometer (resonance frequency for ${ }^{7} \mathrm{Li}$ of 155.4 MHz, Nihon Denshi, JNM-LA400 WB) with magic angle spinning. Line shifts were measured with $\mathrm{LiCl}$ as an external standard. The full lithiated samples at the first cycle were thoroughly washed with diethyl carbonate and then dried under vacuum for $1 \mathrm{~h}$ to remove the electrolyte from the samples.

\section{RESULTS AND DISCUSSION}

\section{1 Charge-discharge characteristics and HTT of}

\section{PAN-based carbons}

XRD data and the results of elemental analysis of PAN-based carbons are summarized in Table 1. The values of $d_{002}$ of the carbons heated above $1000{ }^{\circ} \mathrm{C}$ increased to near $0.37 \mathrm{~nm}$, and becomes larger than that of soft carbons (graphitizable carbons). The hetero atoms of $\mathbf{H}$, $\mathbf{N}$, and $\mathrm{O}$ remained in the PAN-based carbons decreased with increasing heat treatment temperature (HTT).

Figure 1 shows the charge-discharge curves of

Table 1 Elemental analysis and $d_{002}$ of PAN-based carbons heated at various temperatures.

\begin{tabular}{|c|c|c|c|c|c|c|c|c|}
\hline \multirow[b]{2}{*}{$\operatorname{HTT}\left({ }^{\circ} \mathrm{C}\right)$} & \multirow[b]{2}{*}{$d_{002}(\mathrm{~nm})$} & \multicolumn{4}{|c|}{ Weight $\%$} & \multicolumn{3}{|c|}{ Atomic ratio } \\
\hline & & C & $\mathbf{H}$ & $\mathbf{N}$ & 0 & $\mathrm{H} / \mathrm{C}$ & $\mathrm{N} / \mathrm{C}$ & $\mathrm{O} / \mathrm{C}$ \\
\hline 800 & 0.361 & 76.0 & 1.3 & 13.7 & 8.8 & 0.205 & 0.157 & 0.087 \\
\hline 1000 & 0.370 & 83.0 & 1.3 & 5.7 & 10.0 & 0.188 & 0.059 & 0.090 \\
\hline 1100 & 0.368 & 89.6 & 0.9 & 3.2 & 6.3 & 0.121 & 0.031 & 0.053 \\
\hline 1200 & 0.376 & 96.5 & 0.4 & 1.7 & 1.4 & 0.050 & 0.015 & 0.011 \\
\hline
\end{tabular}
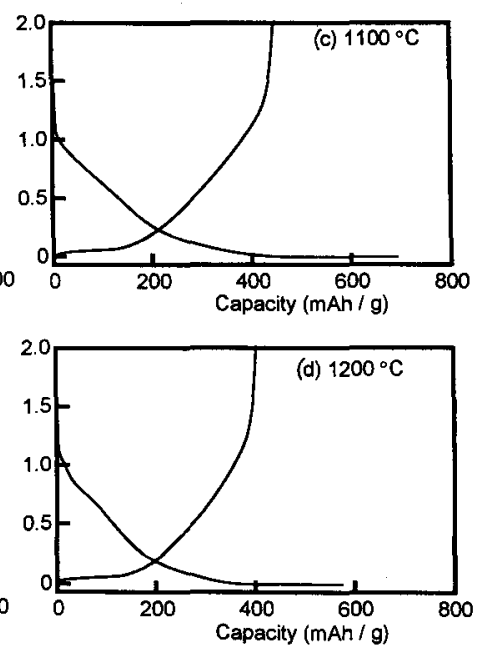

Fig. 1 Charge-discharge curves of PAN-based carbons heated at various temperatures at the first cycle :
(a) $800{ }^{\circ} \mathrm{C}$,
(b) $1000^{\circ} \mathrm{C}$,
(c) $1100^{\circ} \mathrm{C}$,
(d) $1200^{\circ} \mathrm{C}$. 
PAN-based carbons prepared at various HTTs. The large potential hysteresis and the higher reversible capacity than $372 \mathrm{mAh} / \mathrm{g}$ of PAN-based carbons heated at $800{ }^{\circ} \mathrm{C}$ are comparable to those of disordered carbons heated below $1000{ }^{\circ} \mathrm{C} .{ }^{2,4,9,10,12)}$

The treatment at $1000{ }^{\circ} \mathrm{C}$ gives the highest reversible capacity of $517 \mathrm{mAh} / \mathrm{g}$, a coulombic efficiency of $70 \%$, and a potential plateau near $0 \mathrm{~V}$ at the first cycle. The reversible capacity decreased from 517 to $407 \mathrm{mAh} / \mathrm{g}$ with an increase in HTT from 1000 to $1200{ }^{\circ} \mathrm{C}$. The charge-discharge characteristics of PAN-based carbon heated above $1000{ }^{\circ} \mathrm{C}$ are similar to those of other hard carbons. ${ }^{1,6,7,13)}$

\section{3 . 2 Capacity, composition, and nanopores of PAN-} based carbons

Figure 2 shows the reversible capacities for 0 to $0.5 \mathrm{~V}$ and those for 0.5 to $2 \mathrm{~V}$ plotted as a function of HTT. The reversible capacity for 0.5 to $2 \mathrm{~V}$ decreased with increasing HTT, but that for 0 to $0.5 \mathrm{~V}$ increased up to $280 \mathrm{mAh} / \mathrm{g}$ with increasing HTT from 800 to $1000{ }^{\circ} \mathrm{C}$ and retained constant between 1000 and $1200{ }^{\circ} \mathrm{C}$. The total capacities for 0 to $2 \mathrm{~V}$ were significantly divided into two parts. The reversible capacity for 0.5 to 2 $\mathrm{V}$ has been considered to be attributed to lithium extraction from unorganized carbons containing some hetero atoms. ${ }^{16)}$ Figure 3 shows the relationship between the reversible capacity for 0.5 to $2 \mathrm{~V}$ and the atomic ratios of $\mathrm{H} / \mathrm{C}, \mathrm{N} / \mathrm{C}$, and $\mathrm{O}$ /C. The reversible capacity for 0.5 to $2 \mathrm{~V}$

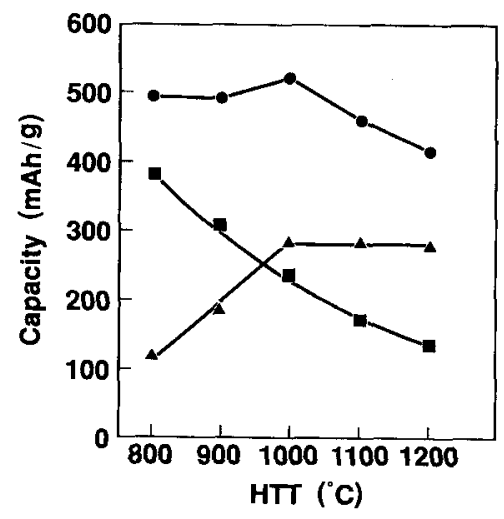

Fig. 2 Relationship between the reversible capacities and HTT of PAN-based carbons: total capacity, capacity for 0.5 to $2 \mathrm{~V}, \Delta$ capacity for 0 to $0.5 \mathrm{~V}$. increases with the $\mathrm{N} / \mathrm{C}$ and the $\mathrm{H} / \mathrm{C}$ atomic ratio. The $\mathrm{O} / \mathrm{C}$ atomic ratio is not well correlated to the capacity, while the linear relationship between the $\mathrm{N} / \mathrm{C}$ atomic ratio and the capacity is observed. Such a relationship supports that the reversible capacity for 0.5 to $2 \mathrm{~V}$ is caused by extraction of a large amount of lithium from the carbons containing nitrogen and hydrogen. ${ }^{16)}$ On the other hand, it has been reported that the insertion and the extraction capacity at the low potential plateau for hard carbons heated between 1000 and $1400{ }^{\circ} \mathrm{C}$ are due to lithium insertion in nanopores. ${ }^{7,13)}$ The nanopores were analyzed from SAXS measurements as shown in Fig. 4. Intensity in the angle of below $0.5^{\circ}$ decreases with an increase in HTT from 1000 to $1200{ }^{\circ} \mathrm{C}$. These profiles indicate that the size of nanopores decreases with an increase in HTT. Figure 5 shows the radius distribution calculated from the profiles in Fig. 4. The radius

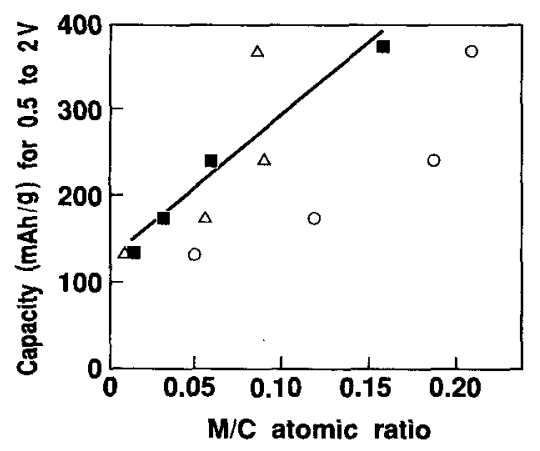

Fig. 3 Relationship between the reversible capacity for 0.5 to $2 \mathrm{~V}$ and atomic ratios $(\mathrm{M} / \mathrm{C})$ of $\mathrm{H} / \mathrm{C}(\mathrm{O}), \mathrm{N} / \mathrm{C}(\mathbf{O})$, and $\mathrm{O} / \mathrm{C}(\triangle)$.

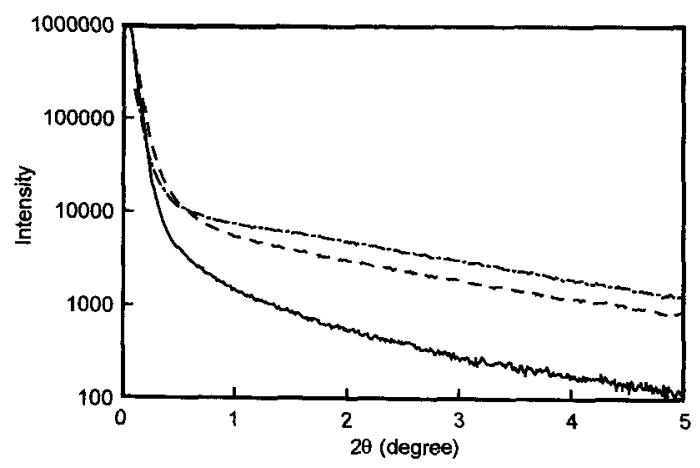

Fig. 4 SAXS profiles for PAN-based carbons heated at $1000{ }^{\circ} \mathrm{C}(-), 1100^{\circ} \mathrm{C}(-\cdot-)$, and $1200^{\circ} \mathrm{C}(-\cdot-)$. 

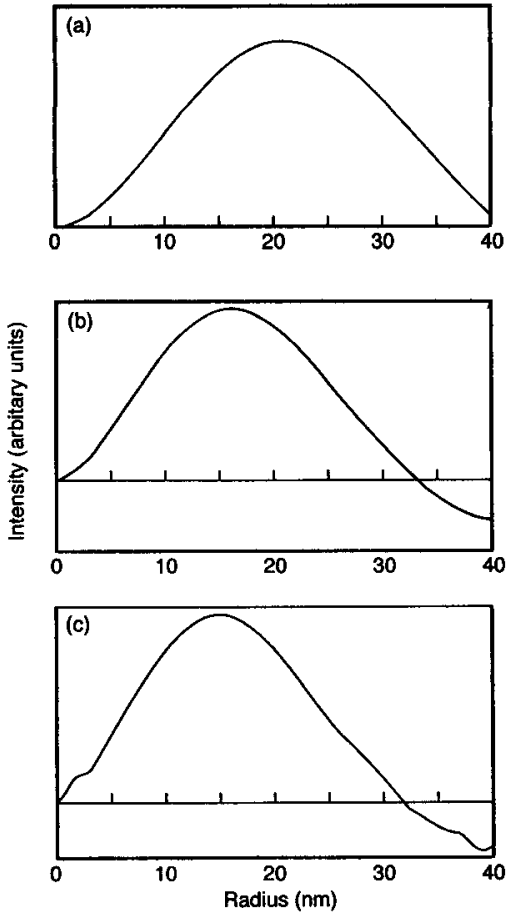

Fig. 5 Radius distribution function of PAN-based carbons heated at $1000{ }^{\circ} \mathrm{C}(\mathrm{a}), 1100^{\circ} \mathrm{C}$ (b), and $1200{ }^{\circ} \mathrm{C}$ (c).

destribution curves below $5 \mathrm{~nm}$ varied significantly for HTT of 1000 to $1200{ }^{\circ} \mathrm{C}$. The distribution in nanopores with an average radius of around $2 \mathrm{~nm}$ were remarkable in the PAN-based carbon heated at $1200{ }^{\circ} \mathrm{C}$. The distribution in size of nanopores becomes narrow as HTT increased from 1000 to $1200{ }^{\circ} \mathrm{C}$. The total volume of the nanopores with the radius of below $5 \mathrm{~nm}$ may be unchanged because the bulk density of the PAN-based carbons was almost constant in the HTT from 1000 to 1200 ${ }^{\circ} \mathrm{C}$. We consider that the total volume is related to the amount of lithium storage in the nanopores. Recently, it was reported that the reversible capacity increased with decreases in the size of nanopores in hard carbons. ${ }^{13)}$ However, from the distribution in Fig. 5 and the reversible capacities for 0 to $0.5 \mathrm{~V}$, the correlation between the size of nanopores in the PAN-based carbons heated from 1000 to $1200{ }^{\circ} \mathrm{C}$ and the reversible capacity was not observed. We consider that the reversible capacity is related to not only the average size of nanopores but also the distribution in size. The nanopores in

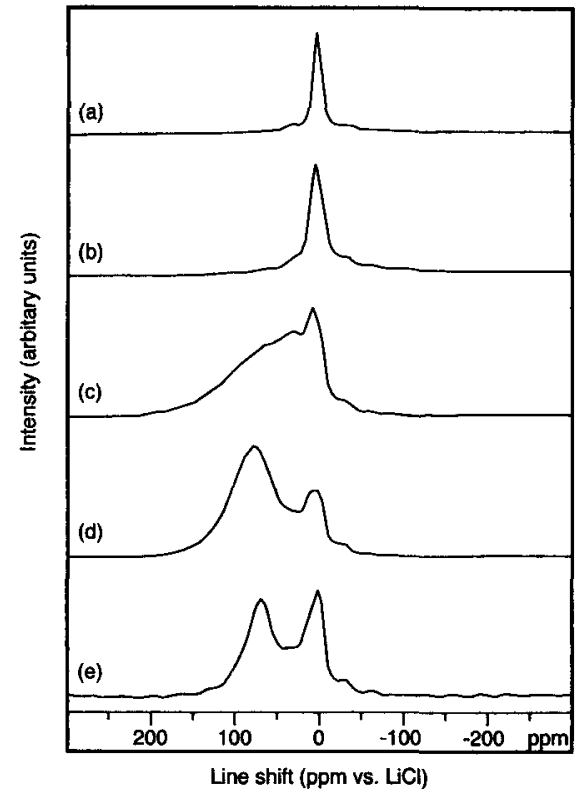

Fig. $6{ }^{7} \mathrm{Li}$ NMR spectra of full lithiated PAN-based carbons heated at $800{ }^{\circ} \mathrm{C}$ (a), $900{ }^{\circ} \mathrm{C}$ (b), $1000{ }^{\circ} \mathrm{C}$ (c), $1100{ }^{\circ} \mathrm{C}(\mathrm{d})$, and $1200{ }^{\circ} \mathrm{C}$ (e) at the first cycle. Lithium insertion capacities of (a), (b), (c), (d), and (e) are 760, $745,709,648$, and $627 \mathrm{mAh} / \mathrm{g}$, respectively.

PAN-based carbon heated at $1000{ }^{\circ} \mathrm{C}$ may have a wide distribution in size.

\section{3 ${ }^{7} \mathrm{Li}$ NMR analysis of lithiated PAN-based carbons}

The lithium storage sites and the chemical species of lithium inserted were investigated from ${ }^{7} \mathrm{Li}$ NMR observation. Figure 6 shows ${ }^{7} \mathrm{Li}$ NMR spectra of the PAN-based carbons after the full lithiation. The PAN-based carbons heated at 800 and $900{ }^{\circ} \mathrm{C}$ exhibit a relatively narrow band from 6 to $10 \mathrm{ppm}$. The narrow band may contain an overlapping component at around $0 \mathrm{ppm}$ since these bands have been also observed in perylenebased carbon heated at $550{ }^{\circ} \mathrm{C}^{16)}$ and hard carbon heated at $1000{ }^{\circ} \mathrm{C} .{ }^{23)}$ We consider that the narrow band from 6 to $10 \mathrm{ppm}$ is assigned to ionic lithium inserted in two reversible sites located in the layer structure and in the unorganized carbon containing hetero atoms of $\mathrm{H}, \mathrm{O}$, and $\mathrm{N}$. On the other hand, the component overlapped at around $0 \mathrm{ppm}$ is considered to be assigned to lithium compounds in irreversible sites located at hydrogen- or nitrogen- 
terminated edges of the aromatic rings and the surface of carbon. The lithium compounds may constitute the solid/electrolyte interface on the surface of carbon formed by electrochemical reduction of the electrolyte. ${ }^{23)}$ The PAN-based carbons heated at $1000{ }^{\circ} \mathrm{C}$ exhibits a broad band from 20 to $100 \mathrm{ppm}$. As HTT increased, this component became a broad band with a peak at a shift of $80 \mathrm{ppm}$, larger than that of lithium intercalated graphite (ca. $41 \mathrm{ppm})$. $^{1524,25)}$ The shift of the broad band is smaller than that of a metal lithium band at $264.7 \mathrm{ppm}^{16)}$ The metal lithium deposition on the PAN-based carbons was not observed. The shift value of the narrow band increased from 6.7 to $17 \mathrm{ppm}$ with an increasing in HTT from 800 to $1200{ }^{\circ} \mathrm{C}$. These shift values below $20 \mathrm{ppm}$ support the proposition that ionic lithium is stored in two reversible sites; the layer structure and the unorganized carbons containing hetero elements. ${ }^{15,16)}$ The shift of $80 \mathrm{ppm}$ for the PAN-based carbons heated at 1100 and $1200{ }^{\circ} \mathrm{C}$ is similarly observed for other hard carbons. ${ }^{7,17)}$ The broad band at $80 \mathrm{ppm}$ is assigned to lithium clusters with metallic character formed in nanopores, ${ }^{7)}$ which corresponds to the low potential plateau in the charge-discharge curves. Consequently, we propose that the hard carbons heated above $1000{ }^{\circ} \mathrm{C}$ have three reversible storage sites characterized as the layer structure, the unorganized carbon containing hetero elements, and the nanopores. The high capacity for hard carbons was attributed to lithium storage in the unorganized carbons containing hetero elements and the nanopores.

\section{CONCLUSIONS}

The PAN-based carbons heated from 1000 to $1200{ }^{\circ} \mathrm{C}$ showed higher reversible capacities than that of $\mathrm{LiC}_{6}(372 \mathrm{mAh} / \mathrm{g})$ with the low potential plateau. The reversible capacity in the potential range for 0.5 to $2 \mathrm{~V}$ was well correlated to the $\mathrm{N} /$ $\mathrm{C}$ and the $\mathrm{H} / \mathrm{C}$ atomic ratio. The high reversible capacity of PAN-based carbons heated below 1000 ${ }^{\circ} \mathrm{C}$ was attributed to lithium extraction from the unorganized carbons containing nitrogen and hydrogen. Nanopores with the radius of around 2 $\mathrm{nm}$ were remarkably observed in the PAN-based carbons heated at $1200{ }^{\circ} \mathrm{C}$. From the results of ${ }^{7} \mathrm{Li}$
NMR observation and SAXS measurements, lithium species in PAN-based carbons heated from 1000 to $1200{ }^{\circ} \mathrm{C}$ could be classified into ionic lithium in the layer structure and in the unorganized carbons containing nitrogen and hydrogen, and lithium clusters with metallic character in the nanopores. The storage of lithium in the unorganized carbons containing hetero elements and the nanopores leads to the high reversible capacity of hard carbons.

\section{References}

1) A. Omaru, H. Azuma, M. Aoki, A. Kita and Y. Nishi, Abstr. 25, p34, The Electrochemical Society Ext. Abstr. Vol. 92-2, Toronto, ON Canada, Oct. 11-16 (1992).

2) T. Ohsaki, A. Satoh and N. Takami, in Proceedings of the 34th Battery Symposium in Japan, Hiroshima, p.79 (1993).

3) J. R. Dahn, A. K. Sleigh, H. Shi, J. N. Reimers, Q. Zhong and B. M. Way, Electrohim. Acta, 38, 1221 (1993).

4) S. Yata, H. Kinoshita, K. Komori, N. Ando, T. Kashiwamura, T. Harada, K. Tanaka, and T. Yamabe, Synth Met., 62, 153 (1994).

5) K. Sato, M. Noguchi, A. Demachi, N. Oki and M. Endo, Science, 264, 556 (1994).

6) N. Sonobe, M. Ishikawa and T. Iwasaki, in Proc. 35th Battery Symp. in Japan, Nagoya, p.47 (1994).

7) A. Nagai, M. Ishikawa, J. Masuko, N. Sonobe, H. Chuman and T. Iwasaki, in Materials for Electrochemical Energy Storage and Conversion-Batteries, Capacitors and Fuel Cell (Eds., D. H. Doughty, B. Vyas, T. Takamura and J. R. Huff), Vol. 393, p.339, Mat. Res. Soc. Symp. Proc. (1995).

8) T. Zheng, Y. Liu, E. W. Fuller, S. Tseng, U. von Sacken and J. R. Dahn, J. Electrochem. Soc., 142, 2581 (1995).

9) A. Mabuchi, K. Tokumitsu, H. Fujimoto and T. Kasuh, $J$. Electrochem. Soc., 142, 1041 (1995).

10) M. Hara, A. Satoh, N. Takami and T. Ohsaki, J. Physical Chem., 99, 16338 (1995).

11) N. Takami, A. Satoh, M. Hara and T. Ohsaki, J. Electrochem. Soc., 142, 371 (1995).

12) T.Zheng, W. R. Mckinnon and J. R. Dahn, J. Electrochem. Soc., 143, 2137 (1996).

13) W. Xing, J. S. Xue, T. Zheng, A. Gibaud and J. R. Dahn, J. Electrochem. Soc., 143, 3482 (1996).

14) Y. Mori, T. Iriyama, T. Hashimoto, S. Yamazaki, F. Kawakami, H. Shiroki and T. Yamabe, J. Power Sources, 56, 205 (1995).

15) K. Tatsumi, T. Akai, T. Imamura, K. Zaghib, N. Iwashita, S. Higuchi and Y. Sawada, J. Electrochem. Soc., 143, 1923 (1996)

16) N. Takami, A. Satoh, T. Ohsaki and M. Kanda, Electrochim. Acta, 42, 2537 (1997).

17) K. Tatsumi, T. Kawamura, S. Higuchi, T. Hosotubo, H. Nakajima and Y. Sawada, J. Power Sources, 68, 263 (1997).

18) W. J. Weydanz., B. M. Way, T. van Buuren and J. R. Dahn, J. Electrochem. Soc., 141, 900 (1994).

19) T. Iijima, K. Suzuki and Y. Masuda, Synth. Met., 73, 9 
(1995).

20) S. Ito, T. Murata, M. Hasegawa, $Y$. Bito and $Y$. Toyoguchi, J. Power Sources, 68, 245 (1997).

21) Y. Jung, M. C. Suh, H. Lee, M. Kim, S. Lee, S. C. Shim and J. Kwak, J. Electrochem. Soc., 144, 4279 (1997).

22) T. Nakajima, M. Koh and M. Takashima, Electrochim. Acta., 43, 883 (1998).

23) Y. Dai, Y. Wang, V. Eshkenazi, E. Peled and S. G.
Greenbaum, J. Electrochem. Soc., 145, 1179 (1998).

24) J. Canard and H. Estrade, Master. Sci. Eng., 31, 173 (1977).

25) K. Tatsumi, K. Zaghib, Y. Sawada, H. Abe and T. Ohsaki, in Rechargeable Lithium and Lithium-Ion Batteries (Eds., S. Megahed, B. M. Barnett and L. Xie), PV 94-28, p.97, The Electrochemical Society Proc. Series, Pennington, NJ (1994). 